\title{
Better Policing through a Paradigm Shift in Public Perception of the Police
}

\author{
Gopala Krishnan Sekharan Nair (Corresponding author) \\ Academy of Language Studies, Universiti Teknologi MARA (UiTM) \\ Dungun Campus, 23000 Dungun, Malaysia
}

Tel: 60-9-8400-8225/60-12-900-2602 E-mail: gopal792@tganu.uitm.edu.my

Azyanee Luqman

Faculty of Business Management, Universiti Teknologi MARA

23000 Dungun, Terengganu, Malaysia

Tel: 60-9-840-3988Ｅ-mail: azyanee@tganu.uitm.edu.my

Thenmolli Vadeveloo

Faculty of Administrative Science and Policy Studies, Universiti Teknologi MARA

23000 Dungun, Terengganu, Malaysia

Tel: 60-9-840-3866 E-mail: thenm020@tganu.uitm.edu.my

Rasaya Marimuthu

Academy of Language Studies, Universiti Teknologi MARA (UiTM)

Pulau Pinang, 13500 Penang, Malaysia

Tel: 60-4-823-3771/60-12-989-270 E-mail: rasay386@ppinang.uitm.edu.my

Saravanan Shanmuggam

Narcotics Division, Royal Malaysian Police, 23000 Dungun, Terengganu, Malaysia

Tel: 60-16-785-4603 E-mail: saravanan_sh@rmp.gov.my

Received: September 13, 2011

Accepted: November 4, $2011 \quad$ Published: March 1, 2012

doi:10.5539/ass.v8n3p113

URL: http://dx.doi.org/10.5539/ass.v8n3p113

\begin{abstract}
The general populace may not always have a good impression of the police force. It is essential that the public should have a positive perception of the police force so that the force may be able to count on public cooperation in their efforts to combat crime and maintain public order. This paper investigated the factors that influenced the public opinion of the police such as police effectiveness in combating crime, corruption, brutality and personal links between police and the public. It is a qualitative study comprising 30 respondents from Terengganu and 30 from Penang. It was found that most of the educated members were not happy with the police as they felt that the police could be more effective in combating crime. In addition, respondents expressed dissatisfaction with the prevalence of corruption and brutality in the police force. They also felt that the actions taken by the police to curb these ills are inadequate. The police should further reduce crime and seen to be acting sternly against corruption and brutality in order to regain public confidence and win their cooperation in combating crime. Further research should be carried out on a quantitative basis using a much larger sample.
\end{abstract}

Keywords: Public cooperation, Public opinion, Police force, Police performance, Crime 


\section{Introduction}

In recent times, the public has been rather critical of the police force. The public perceive the police as being corrupt, abusing their power and ineffective in carrying out policing work. It is essential that the public should have a positive perception of the police force so that the force may be able to count on public cooperation in their efforts to combat crime and maintain public order. Those who have pleasant experiences with the police generally have positive opinions of the police and are more inclined to extend cooperation to the police force (Hawk-Tourtelot, 2010).

According to $\mathrm{Wu}$ (2009), research on public perception of the police is vital because how the public conceptualizes and evaluates the local police can directly shape the way they respond to the police, the political support and cooperation they render to the police, and their willingness to participate in police and community anti-crime programs and efforts.

The good opinion of the public must be consistent; the image of the police should not be compared to a swinging pendulum on a clock (Schanlaub, 2004). In view of this, this study intends to find out the factors that would influence the public perceptions of the police force. This paper investigated qualitatively whether the public perceptions of the level of crime and disorder in the country were instrumental in shaping the public perceptions of the police. In addition investigation was also carried out to find out whether the public perceptions of the prevalence of corruption in the police force were a factor in shaping their negative perception of the police force.

These researchers also investigated whether the public opinion of the efforts taken by the police force to curb corruption helps in creating a better perception of the police force. Also investigated was whether the public believed that there was brutality in the police force and whether this believes played a part in shaping the public perception of the police.

A more positive opinion of the police would result in a greater level of cooperation thus resulting in more effective policing on the part of the police. An ineffective police also causes the public to be disillusioned with the government of the day as they blame police ineffectuality on the government's inability to institute a viable police force.

\subsection{Objectives}

To determine whether the public perceptions of the level of crime and disorder in the country was instrumental in shaping the public perceptions of the police.

To determine whether the public perceptions of the prevalence of corruption in the police force were a factor in shaping their negative perception of the police force.

To determine whether the public believed that there was brutality in the police force and whether this belief played a part in shaping the public perception of the police.

To determine whether residents with informal police contacts had more positive perceptions than residents with formal contacts.

To determine whether residents' opinion of police performance varies according to education level.

\section{Literature Review}

In most communities the police are unable to get the desired cooperation from the public largely due to the public having an adverse opinion of the police, (Hennigan et al., 2002; Skogan, 1990). In many cases the chiefs of police have tried in vain to improve ties with the public but often facing disappointment.

Lack of a symbiotic relationship between the public and police may curtail police efforts at reducing crime (Skogan and Harnett, 1997; Sampson and Raudenbush, 1999; Sampson et al., 1999). The police are often frustrated that their efforts to improve ties with the public are not yeilding much results. Often a disgruntled police force blames the public and labels them as ingrates for failing to appreciate police overtures towards a better relationship. Such a case often results in a demotivated crime fighting force (Maxson et al., 1999; Hennigan et al., 2001). Kansas City Police Department (1977) as cited in Brandl and Horvath (1991) reported that often the police failed to realize that the public opinion of the police force is a crucial factor in fostering ties between the two.

Poor public opinion of the police results in poor public response towards police efforts at friendship (Brown and Coulter, 1983). Failed efforts at friendship results in the police getting demotivated as they perceive the public to be uncooperative and ungrateful. Demotivation among the police force results in more crime as a result of uninspired enforcement. When crime rate goes up there is a further dip in the public perception of the police resulting in a greater antagonism towards the police on the part of the public (Carter, 1985). 
This reduced opinion of the police would result in more difficulty in securing public cooperation. Thus a vicious circle prevails where lack of public cooperation leads to a demotivated police force and more crime, increased crime then creates a further dip in the public opinion of the police and an increased reluctance towards better ties with the police (Jesilow et al., 1995). Figure 1 shows the depiction of the vicious circle as envisaged by Jesilow et al. (1995).

In Malaysia too there has been a lot of antagonism between the public and the police although the police have made efforts to build ties with the public. However public perception is best improved by a reduction in the crime rate. Thus far there has been no suggestion of this kind of multi-pronged approach in Malaysia. It is hoped that this new model of approach would result in greater cooperation between public and the police and the consequently more effective crime control as such an approach has worked elsewhere (Sampson et al., 1998).

\section{Methodology}

The study was carried out by conducting interviews among members of the public. The researchers interviewed 30 people in Terengganu and 30 people in Penang. In both locations it was ensured that at least half the sample would consist of educated members of the public such as degree holders whilst the other half would comprise those less educated, such as those running roadside stalls and laborers.

Basically this study is qualitative in nature. 30 people in Terengganu and 30 people in Penang will comprise the sample. This sample would represent the West coast and East coast population of Malaysia. The sample would be randomly selected. The sample would be nonetheless stratified so that it reflects both the educated and the less educated sector of the nation.

An instrument consisting of interview questions will be formulated to gather data which will be analyzed to answer the research questions as well as fulfill the objectives of the study. Based on the data collected from the interviews, the researchers would proceed to come up with the new concept of enhancing ties between the public and the police and this will certainly give the government a better image.

The data obtained from the interview would be analyzed to meet the objectives of the study. The findings will be used for reframing the current approach so that new strategies can be deployed for greater public and police cooperation. The implications of the findings, recommendations and suggestions for further research would also be given.

\section{Findings and Discussion}

4.1 Is the public perception of the level of crime and disorder in the country instrumental in shaping their perception of the police?

Most of the educated respondents expressed anxiety over the level of crime in society. The educated fraternity appears to be reading newspapers and also alternative online media. The high incidence of crime in society makes them feel that the police force could do more in reducing the level of crime. Members of the educated fraternity stated that they have constant fear of being victims of crime. They admitted that their opinion of the police force is influence by the prevalence of the crime in the society.

They also stressed that their opinion of the police would certainly be a lot higher if the police are more effective in combating crime. They stated that they frequently come across cases of rape, robbery and murder in newspapers. Some of them are frightened of crime statistics; they stated that no less than one person gets murdered, raped or robbed daily. Members of the educated fraternity also stated that they do have some apprehension of being robbed as they retire to sleep every night.

4.2 Is the public perception of the prevalence of corruption in the police force a factor in shaping their negative perception of the police force?

Again, it is the education fraternity who were more critical of corruption among the police force. They admitted that their perception of corruption among the police force does jeopardize their good opinion of the force. They felt that the police authorities could do more to curb corruption in the police force.

They also express unhappiness with the attitude taken by the police towards allegations of corruption by the public. They claimed that in many instances, the police merely retorted that the public should report if they have evidence of corruption in the force. The respondents feel that the police should understand that it is not easy for a member of the public to make a report to the police against the fellow member of the police. They felt that the police should have their own mechanism to combat corruption in the force. 
4.3 Does the public believe that there is brutality in the police force and whether this belief plays a part in shaping the public perception of the police?

By and the large both the educated and the less educated fraternity do believe that individual members of the police force do sometimes go over board and deal with suspects in an overly brutal manner resulting in injury, insult and on occasion even death. They felt that, the police higher authority should not be eager to defend their personnel who are guilty of brutality but should objectively and impartially investigate incidences of brutality and if necessary institute disciplinary actions against the personnel concerned. The respondents support the action taken by the police in the case which involved the shooting of the school boy, Amirul Rasyid (Ong, 2010, December 7). Respondents also felt that the police should investigate and take action on other allegations of brutality even though their cases are not high profile.

4.4 Do residents with informal police contacts have more positive perceptions than residents with formal contacts?

Clearly those who had friends in the police force are inclined to have a more favorable view of the police. It would certainly help to foster the relations between the public and the police, if the police attempt to get to know people in their area of jurisdiction on a more personal level.

4.5 Do residents opinion of police performance varies according to education level?

On the whole, those who are more educated appear more critical of the police force. This could be due to being more aware of the prevalence of crime through newspapers and other sources.

\section{Conclusion}

The core business of the police force is peacekeeping. Unless they are seen to be performing their core business to the satisfaction of the public, their image in the eyes of the public will not improve. In order to create a paradigm shift in public perception of the police, the authorities must work on those factors that cause the public to lower their esteem of the police. Better policing can result if there is better cooperation from the public. It is evident that the public perception of the police is related to their perception of the police performance in combating crime, curbing corruption and brutality. Any attempt to redeem police image would involve rehabilitating public perception by more effective crime control measures. A higher esteem of the police would ensure more cooperation from the public and in turn better crime fighting effectiveness. The key to better public image is dependent on the police performing their core duties more effectively.

Relations can also be improved if the police make efforts to build relationship with members of the community around them. However no amount of public relation work would be of any use if the public are not satisfied with the manner in which the police go about their core business of peacekeeping. If the public perception of the police is improved, then the public and the police would become partners in combating crime. There would be less mistrust and more beneficial collaboration.

\section{References}

Brandl, S. G. \& Horvath, F. (1991). Crime-victim evaluation of police investigative performance. Journal of Criminal Justice. 19, 293-305. http://dx.doi.org/10.1016/0047-2352(91)90008-J

Brown, K. \& Coulter, P. B. (1983). Subjective and objective measure of police performance. Public Administration Review. 43, 50-58. http://dx.doi.org/10.2307/975299

Carter, D. L. (1985). Hispanic perception of police performance: An empirical assessment. Journal of Criminal Justice. 13, 487-500. http://dx.doi.org/10.1016/0047-2352(85)90078-9

Hawk-Tourtelot, S. R. (2010). College students' perceptions of the police:The role of justice education. Unpublished masters dissertation, University of Arkansas, United States of America.

Hennigan, K., Maxson, C., Sloane D. C. \& Ranney, M. (2001). Community views on crime and policing: Survey mode effects on bias in community surveys. Los Angeles: University of Southern California.

Hennigan, K., Maxson, C., Sloane D. C. \& Ranney, M. (2002). Community views on crime and policing: Survey mode effects on bias in community surveys. Justice Quarterly. 19(3), 565-587. http://dx.doi.org/10.1080/07418820200095351

Jesilow, P., Meyer, J. \& Namazzi, N. (1995). Public attitudes toward the police. American Journal of Police, 14 (2), 67-88. http://dx.doi.org/10.1108/07358549510102767

Maxson, C., Hennigan, K., Sloane, D. C. \& Ranney, M. (1999). The community component of community policing in Los Angeles. Final Report to the National Institute of Justice. 
Ong, H. S. (2010, December 7). Two Cops Beat Me Up, Says Teenager in Amirulrasyid Trial. The Star. [Online] Available: http://www.thestar.com.my/news (February 21, 2011)

Sampson, R. J. \& Raudenbush, S. W. (1999). Systematic social observation of public spaces: A new look at disorder in urban neighborhoods. American Journal of Sociology, 105 (3), 603-651. http://dx.doi.org/10.1086/210356

Sampson, R. J., Raudenbush, S. W. \& Earls, F. (1998). Neighborhood collective efficacy: Does it help reduce violence? Research preview. Washington, DC: U.S. Department of Justice, National Institute of Justice, NCJ 184377.

Sampson, R. J., Raudenbush, S. W. \& Earls, F. (1999). Neighborhoods and violent crime: A multilevel study of collective efficacy. Journal of Science, 277 (1077), 918-924.

Schanlaub, R. (2004). Public perception of police. Law \& Order, 52 (7), 140-141.

Skogan, W. \& Harnett, S. (1997). Community policing Chicago style. New York: Free Press.

Skogan, W. (1990). Disorder and decline: Crime and the spiral of decay in American neighborhoods. New York: Free Press.

$\mathrm{Wu}, \mathrm{Y}$. (2009). Race and policing: Chinese immigrants'/American's perception of the police. Unpublished doctoral dissertation, University of Delaware, United States of America.

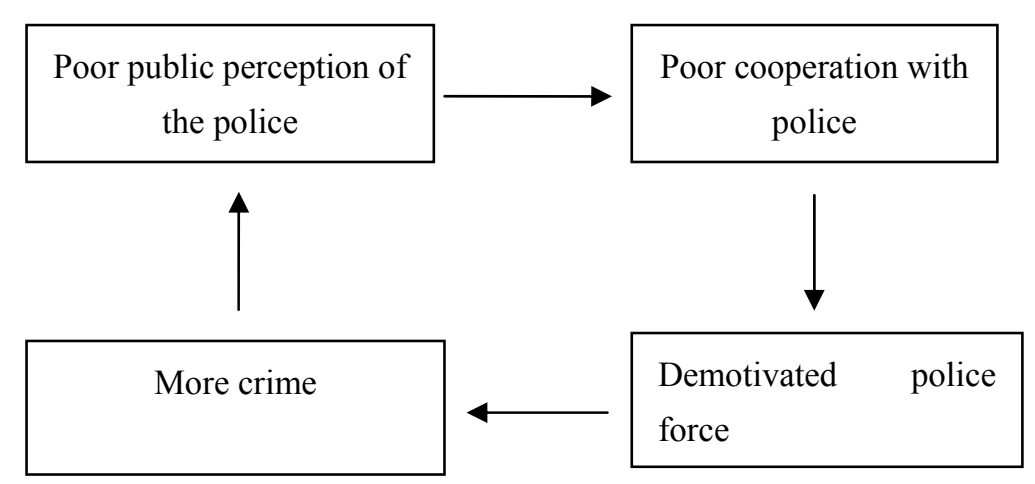

Figure 1. Depiction of the vicious circle as envisaged by Jesilow et al. (1995) 